\title{
THE RELATIONSHIP BETWEEN MANGANISM AND THE WORKPLACE ENVIRONMENT IN CHINA
}

\section{YONGYI WANG ${ }^{1}$, JIAN XUE ${ }^{2}$, SHUQUN CHENG ${ }^{3}$, YUBIN DING $^{3}$, JUNLIN HE $^{3}$, XUEQING LIU ${ }^{3}$, XUEMEI CHEN $^{3}$, YINGXIONG WANG ${ }^{3}$, XIANGYU FENG ${ }^{4}$, and YINYIN XIA ${ }^{2}$}

${ }^{1}$ Chongqing Prevention and Treatment Center for Occupational Diseases, Chongqing, People's Republic of China

${ }^{2}$ Chongqing Medical University, Chongqing, People's Republic of China

Department of Occupational and Environmental Hygiene

${ }^{3}$ Chongqing Medical University, Chongqing, People's Republic of China

Department of Genetics, School of Public Health

${ }^{4}$ Chongqing Enter Exit Inspection and Quarantine Bureau, Chongqing, China

\begin{abstract}
Manganese is a trace element and a cofactor of many enzymes, so it is essential for physiologic functioning, but it is also a neurotoxin at high doses. Manganism is most often caused by occupational exposure. It is manifested by a myriad of signs and symptoms ranging from the neurasthenia syndrome, such as headache and dizziness, to the Parkinson-like syndrome, depending on the blood manganese levels as well as the duration of exposure. We are reporting a case of manganism using both clinical and occupational hygiene investigation methods. The patient presented the neurasthenia syndrome accompanied by hypertonicity of arm muscles and was diagnosed to have mild chronic manganism. Finally, the patient was discharged from the hospital after the treatment had improved her condition. In China, there are many chronic manganese cases, partly due to a rapid industrial development with great use of $\mathrm{Mn}$ and the low self-protection awareness among the workers and the factories management that cannot catch up with the speed of the economical development. Therefore, factories are responsible for improving the conditions at the workplace.
\end{abstract}

Key words:

Manganese, Occupational exposure, Welding, Mining, Occupational intoxication, Chronic manganism

\section{INTRODUCTION}

Manganese $(\mathrm{Mn})$ is a metal used in numerous industries including welding, mining, steel production, and formulating gasoline additives. However, it is also required for our proper functioning in a variety of physiological processes [1]. Mn plays a role in immune response, blood sugar homeostasis, adenosine triphosphate (ATP) regulation, reproduction, digestion, and bone growth [2]. It is an important cofactor for a variety of enzymes including oxidoreductases, transferases, hydrolases, lyases, isomerases and ligases. In the central nervous system (CNS), $\mathrm{Mn}$ is also involved in the regulation of superoxide-dismutase 2 (SOD 2) which is the major cellular antioxidant enzyme [3], the gliaspecific glutamine synthetase (GS) [4], and glutamate-glutamine cycling and ammonia detoxification $[5,6]$. Despite its essentiality, exposure to excessive Mn levels is associated with an irreversible brain disease characterized by psychiatric and motor disturbances $[7,8]$. This disorder is referred to as manganism.

Received: February 27, 2012. Accepted: June 15, 2012.

Address reprint request to: Y. Xia, Department of Occupational and Environmental Hygiene, Chongqing Medical University, Chongqing 400016, China (e-mail: kendraxia@yahoo.com.cn). 
Chronic manganese intoxication resulting from the $\mathrm{Mn}$ intake above the daily requirement or exposure for long duration is known as an occupational disease observed mostly in industrial workers [9]. Some studies have reported associations between $\mathrm{Mn}$ exposure in drinking water and described cognitive/behavioral problems in children in Quebec [10], Bangladesh [11], and Taiwan [12]. In healthcare facilities, there are many chronic manganese poisoning cases due to Mn usage in industry. For example, excessive Mn exposure occurs in occupations such as ferroalloy smelting [13], welding [14,15], mining [16], battery assembly [17], and the manufacturing of glass and ceramics [18]. In China, there are quite a few reports on occupational Mn poisoning [19]. We are describing the case of a woman exposed to excessive $\mathrm{Mn}$ levels at the workplace.

In this report, we are describing the investigation of a case of manganism following excessive exposure to $\mathrm{Mn}$ at the workplace. The objectives of this investigation were to confirm the diagnosis, identify the underlying etiology, recommend control measures, and assess whether other persons were at risk as well.

\section{CASE}

A 36 years old woman had been occupationally exposed to manganese for 17 years (1991-2008). She was employed in a coal mine and engaged in electric and gas welding. She had never worn mask in her working time, which amounted to 3 hours per day for six consecutive days a week. The Mn concentration (4 h TWA) in the air of her workplace was $0.29 \mathrm{mg} / \mathrm{m}^{3}$ (Occupational exposure limit being $0.15 \mathrm{mg} / \mathrm{m}^{3}$ ) [20], because there was no efficient and effective equipment for mechanical ventilation. The patient had suffered from insomnia, limb weakness, giddiness, and headache for 3 months before hospital admission. Her physical examination tests on admission were all within normal ranges, except for hypertonicity of arm muscles.
The electrocardiogram and electroencephalogram were normal. The laboratory tests showed normal blood, urine, and feces results and normal hepatic and renal functions. Our center reported this case to the Chongqing health supervision agency and made an occupational hygiene investigation at the patient's workplace. We detected the Mn concentration in the air of her workplace and found that the mean reached $0.29 \mathrm{mg} / \mathrm{m}^{3}$, which is above the level of the occupational exposure limit in China. The final diagnosis of the neurasthenia syndrome accompanied by hypertonicity of arm muscles caused by chronic overexposure to Mn was formulated. Subsequently, supportive, complementary and electronic biofeedback therapies were applied. The patient was treated with two kinds of traditional Chinese medicine, one being ginkgo leaf extract and diphyridamole injections, and the other acanthopanax senticosus injections, used to improve microcirculation. Each course of the treatment included taking medicine continuously for seven days, followed by a seven-day break. The other treatment included citicoline sodium injections applied to repair and regenerate the nerves, estazolam and electronic biofeedback therapies for insomnia. Then, the patient's condition improved and she was discharged from hospital after the two-month treatment.

Based on the data from the occupational hygiene investigation at the patient's workplace, we found that the platoon fans as the major device of mechanical ventilation were used, but this mode was inefficacious, because the Mn level was higher than the admissible limit. As for the worker's individual protection, although the workers were provided masks, they did not wear them due to the lack of supervision and self-protection awareness. As regards the enterprise, it lacked routine data files covering the workers' physical examination information concerning their exposure to chemicals. The enterprise did not monitor the level of exposure to manganese or any others substances at this workplace, furthermore it did 
not establish and kept the files of workers' physical examination. Such misconducts contradict the provisions of the Code of Occupational Diseases Prevention in force in the PRC. At same time, there were also three other welders who had been exposed to high Mn levels at the workplace for a long time.

\section{DISCUSSION}

The patient's symptoms and the occupational exposure assessment were consistent with the chronic low-level exposure pattern. The symptoms of manganism vary from the mental excitement, headaches, fatigue, decreased memory and concentration, dizziness and insomnia to a Parkinsonlike disease [21-26]. Low-level exposures to Mn can result in neuropsychological changes with few or none neurological changes observed for manganism [27]. The performance of Mn workers is less precise and effective in tasks that require coordinated, sequential, alternating movements at high speed, i.e. the functions regulated by the extrapyramidal system [28-31]. Various countries have set acceptable environmental exposures to $\mathrm{Mn}$ at the levels ranging from 0.05 to $31.5 \mu \mathrm{g} / \mathrm{m}^{3}$. The current workplace threshold limit value for Mn in the USA is $0.2 \mathrm{mg} / \mathrm{m}^{3}$ [32] and in China $0.15 \mathrm{mg} / \mathrm{m}^{3}$ [20]. Due to the results of our occupational hygiene investigation and the knowledge of these reports, although the other 3 welders that worked with our patient had no symptom of manganism, we had a reason to believe that those 3 welders are at risk of developing manganism. Bearing in mind the health of the welders and the benefit of this mine, the enterprise must take measures to improve their work environment, for example, by enhancing the efficacy of the ventilation system and obliging the workers to wear masks.

China is a developing country, and in the society experiencing such a rapid development of economy, the demand for workers in the area of mining, smelting, welding and steel production is usually observed to drastically increase.
Manganese poisoning cases were ceaselessly reported in China. A prevention and treatment center for occupational diseases in the north of China diagnosed 105 chronic manganese intoxications from 1990 to 2005 [33]. Another prevention and treatment center for occupational diseases received 69 manganism cases from 2002 to 2005, 15 cases from coal mines, 20 cases from the chemical industry, 17 cases from the petrochemical industry, 15 cases from the metallurgy industry, and 2 cases came from another industry [34]. An occupational health examination was conducted for 1160 electric welders and 19 people were diagnosed to have chronic manganese (Wang, 2003) [35]. All the reports indicated that manganism is still a serious problem in the area of prevention and control of occupational diseases.

In China, health supervision agencies control if the enterprises detect the Mn levels at the workplace as part of their health protection routine, and the agencies also go to different factories, chosen randomly, to require the original data. If they find something potentially dangerous, they give advice to those enterprises so that they can correct them in time. While there are some illegal factories, hidden in the country, health supervision agencies do not know they exit. Usually, when some persons who worked in these factories go to the hospital, the hospital reports such fact to the agency, and then these factories are found. Therefore, increasing the self-protection awareness is essential for workers who should be able to distinguish whether their workplace is safe or not. The Chinese prevention and treatment centers for occupational diseases have broadcasted to workers how to strengthen their personal protection on the media, and Chinese government offers funds and an open media platform to broadcast such announcement. Finally, the workers are gaining some self-protection awareness, but still not enough. In China, the employers have the legal obligation to control the exposure to toxic substances. If they do not, they can be accused of violating the provisions contained in the 
Code of Occupational Diseases Prevention in force in the PRC. A worker suffering from an occupational disease has the right to sue the enterprise. In the described case, the mine was a legal one, but the management of the mine is not very proficient, especially in the area of occupational health. Therefore, our center offered to provide some advice to the enterprise, which should oblige its workers to wear the protective equipment and establish occupational health files containing the results of their workers' health examination, as well as monitor the Mn levels as part of their health prevention routine. Subsequently, the Chongqing health supervision agency included this enterprise into its blacklist.

\section{REFERENCES}

1. Erikson KM, Syversen T, Aschner JL, Aschner M. Interactions between excessive manganese exposures and dietary irondeficiency in neurodegeneration. Environ Toxicol Pharmacol 2005;19(3):415-21. DOI 10.1016/j.etap.2004.12.053.

2. Aschner JL, Aschner M. Nutritional aspects of manganese homeostasis. Mol Aspects Med 2005;26(4-5):353-62. DOI 10.1016/j.mam.2005.07.003.

3. Bidmon HJ, Kato K, Schleicher A, Witte OW, Zilles K. Transient increase of manganese-superoxide dismutase in remote brain areas after focal photothrombotic cortical lesion. Stroke 1998;29(1):203-10; Discussion: 211. DOI 10.1161/01. STR.29.1.203.

4. Morello M,ZattaP,ZambenedettiP,Martorana A,D'AngeloV, Melchiorri G, et al. Manganese intoxication decreases the expression of manganoproteins in the rat basal ganglia: an immunohistochemical study. Brain Res Bull 2007;74(6):406-15. DOI 10.1016/j.brainresbull.2007.07.011.

5. Wedler FC, Denman RB. Glutamine synthetase: the major Mn (II) enzyme in mammalian brain. Curr Top Cell Regul 1984;24:153-69.

6. Takeda A. Manganese action in brain function. Brain Res Brain Res Rev 2003;41:79-87.
7. Pal KPA, Samii A, Calne DB. Manganese neurotoxicity: A review of clinical features, imaging and pathology. Neurotoxicology 1999;20:227-38.

8. Stredrick DL, Stokes AH, Travis JW, Willard MF, Johnson EA, Lash LH, et al. Manganese-induced cytotoxicity in dopamine-producing cells. Neurotoxicology 2004;25:543-53. DOI 10.1016/j.neuro.2003.08.006.

9. Perl DP, Olanow CW. The neuropathology of manganese induced parkinsonism. J Neuropathol Exp Neurol 2007;66(8):675-82. DOI 10.1097/nen.0b013e31812503cf.

10. Bouchard M, Laforest F, Vandelac L, Bellinger D, Mergler D. Hair manganese and hyperactive behaviors: pilot study of school-age children exposed through tap water. Environ Health Perspect 2007;115:122-7. DOI 10.1289/ehp.9504.

11. Wasserman GA, Liu X, Parvez F, Ahsan H, Levy D, FactorLitvak P, et al. Water manganese exposure and children's intellectual function in Araihazar, Bangladesh. Environ Health Perspect 2006;114:124-9. DOI 10.1289/ehp.8030.

12. He P, Liu DH, Zhang GQ. Effects of high-level-manganese sewage irrigation on children's neurobehaviour. Zhonghua Yu FangYi Xue Za Zhi 1994;28(4):216-8 [in Chinese].

13. Bast-Pettersen R, Ellingsen DG, Hetland SM, Thomassen Y. Neuropsychological function in manganese alloy plant workers. Int Arch Occup Environ Health 2004;77:277-87. DOI 10.1007/s00420-003-0491-0.

14. Bowler RM, Nakagawa S, Drezgic M, Roels HA, Park RM, Diamond E, et al. Sequelae of fume exposure in confined space welding: a neurological and neuropsychological case series. Neurotoxicology 2007;28:298-311. DOI 10.1016/j. neuro.2006.11.001.

15. Josephs KA, Ahlskog JE, Klos KJ, Kumar N, Fealey RD, Trenerry MR, et al. Neurologic manifestations in welders with pallidal MRI T1 hyperintensity. Neurology 2005;64:2033-9. DOI 10.1212/01.WNL.0000167411.93483.A1.

16. Montes S, Riojas-Rodriguez H, Sabido-Pedraza E, Rios C. Biomarkers of manganese exposure in a population living close to a mine and mineral processing plant in Mexico. Environ Res 2008;106:89-95. DOI 10.1016/j.envres.2007.08.008. 
17. Bader M, Dietz MC, Ihrig A, Triebig G. Biomonitoring of manganese in blood, urine and axillary hair following low-dose exposure during the manufacture of dry cell batteries. Int Arch Occup Environ Health 1999;72:521-7.

18. Srivastava AK, Gupta BN, Mathur N, Murty RC, Garg N, Chandra SV. An investigation of metal concentrations in blood of industrial workers. Vet Hum Toxicol 1991;33:280-2.

19. Song Y, Wang WJ, Zhang HY. Investigation on occupational risks of welding workers in a factory. Zhonghua Lao Dong Wei Sheng Zhi Ye Bing Za Zhi 2010;28(1):36-7 [in Chinese].

20. The National Occupational Health Standards In China. Manganese and inorganic compounds GBZ2.1-2007 [in Chinese].

21. Flinn RH, Neal PA, Fulton WB. Industrial manganese poisoning. Ind Hyg Toxicol 1941;23(8):374-87.

22. Rodier J. Manganese poisoning in Moroccan miners. Br J Ind Med 1955;12(1):21-35.

23. Mena I, Marin O, Fuenzalida S, Cotzias GC. Chronic manganese poisoning. Clinical picture and manganese turnover. Neurology 1967;17(2):128-36.

24. Barrington WW, Angle CR, Willcockson NK, Padula MA, Korn T. Autonomic function in manganese alloy workers. Environ Res 1998;78(1):50-8. DOI: 10.1006/enrs.1997.3826.

25. Sińczuk-Walczak H, Jakubowski M, Matczak W. Neurological and neurophysiological examinations of workers occupationally exposed to manganese. Int J Occup Med Environ Health 2001;14(4):329-37.

26. Bowler RM, Gysens S, Diamond E, Booty A, Hartney C, Roels HA. Neuropsychological sequelae of exposure to welding fumes in a group of occupationally exposed men. Int J Hyg Environ Health 2003;206(6):517-29.
27. Stopford W. Welding and Exposures to Manganese Assessment of Neurological Adverse Effects. Durham: Duke University Medical Center; 2005. p. 24.

28. Saric M, Markicevic A, Hrustic O. Occupational exposure to manganese. Br J Ind Med 1977;34(2):114-8.

29. Roels H, Sarhan MJ, Hanotiau I, de Fays M, Genet P, Bernard A, et al. Preclinical toxic effects of manganese in workers from a Mn salts and oxides producing plant. Sci Total Environ 1985;42(1-2):201-6. DOI 10.1016/0048-9697(85) 900221.

30. Beuter A, Mergler D, de Geoffroy A, Carriere L, Belanger S, Varghese L, et al. Diadochokinesimetry: a study of patients with Parkinson's Disease and manganese exposed workers. Neurotoxicology 1994;15(3):655-64.

31. Lucchini R, Apostoli P, Perrone C, Placidi D, Albini E, Migliorati P, et al. Long-term exposure to "low levels" of manganese oxides and neurofunctional changes in ferroalloy workers. Neurotoxicology 1999;20(2-3):287-97.

32. ACGIH. Threshold limit values for chemical substances and physical agents and biological exposure indices for 1995-1996. Cincinnati, OH: American Conference of Governmental Industrial Hygienists; 1996.

33. Shang B, Fu EH. Clinical analysis on 11 cases of chronic manganism complicated with welder's pneumoconiosis. Chin J Ind Med 2008;21(4):240-1 [in Chinese].

34. Xie SJ. Data analysis of occupational disease among welding workers in Taian from 2002 to 2005. Prevent Med Trib 2007;13(3):288 [in Chinese].

35. Wang X. 1160 welders' health condition analysis. Occup Health 2003;19(4):9-10 [in Chinese].

This work is available in Open Access model and licensed under a Creative Commons Attribution-NonCommercial 3.0 Poland License - http://creativecommons.org/ licenses/by-nc/3.0/pl/deed.en. 